\title{
A112 ヘアレスラットより摘出した皮店組織の生体力学的特性評価
}

\author{
Biomechanical characteristics of dermal tissues obtained from hairless rats

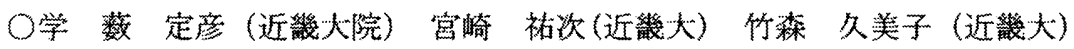 \\ 伊藤 湝行 (近畿大) 正山本 衛 (近畿大) \\ Sadahiko YABU, Kinki University, Kinokawa, Wakayama 649-6493. \\ Yuji MIYAZAKI, Kinki University. \\ Kumiko TAKEMORI, Kinki University. \\ Hiroyuki ITO, Kinki University. \\ Ei YAMAMOTO, Kinki University.
}

Key Words : Biomechanics, Skin, Tensile property, Collagen, Collagenase.

\section{1. 緒言}

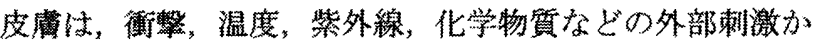

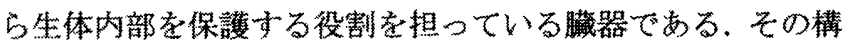

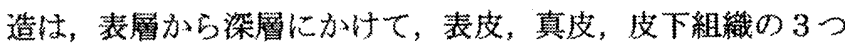

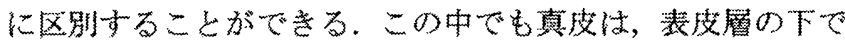

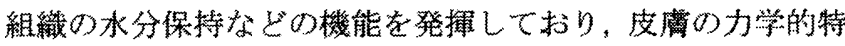

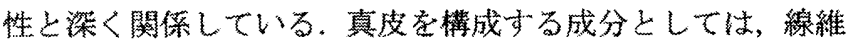

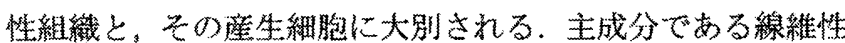
組蟣の大部分がニラーダン線維加ら䅜成されており，その他

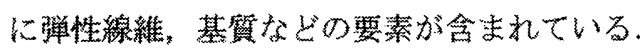

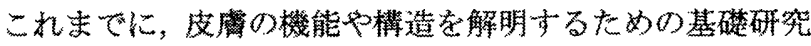

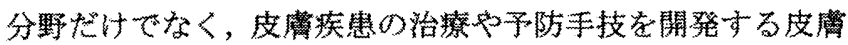

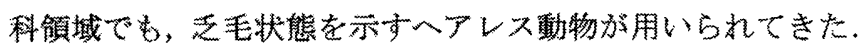

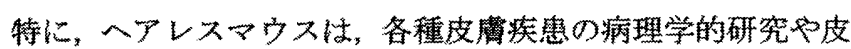

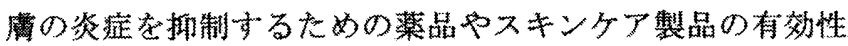

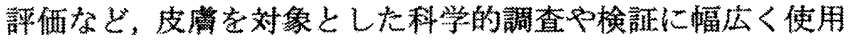
されている。一力で大星の陚料党採取できるという利点为ら

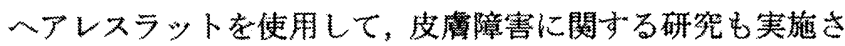

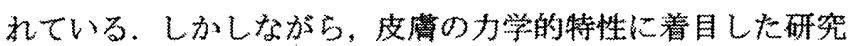

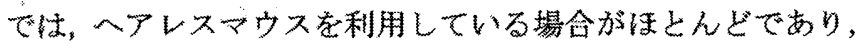
ヘマレスラットの皮薄の力学的特性について、参照できるで

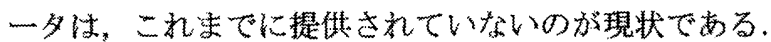

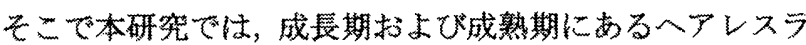

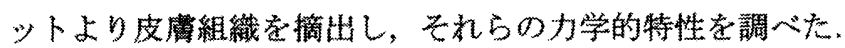

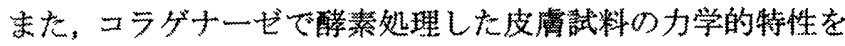
求めることで，組織の特性に対与るコラーダン成分の力学的

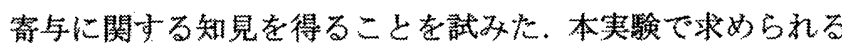

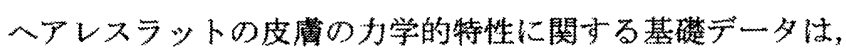

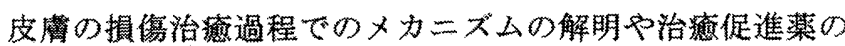
開発に結U付く娄のと推祭される。

\section{2. 実験方法}

\section{$2-1$ 実験試料}

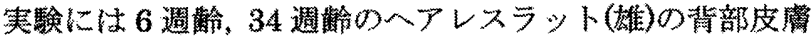
を用いた。されらより JSダンベル状 7 号形の䟼料甞作製し，

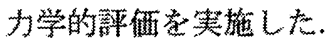

\section{2-2 酵暴处理}

それぞれの陚料を $37^{\circ} \mathrm{C}$ に保ったコラダナ一を溶被に漫漬

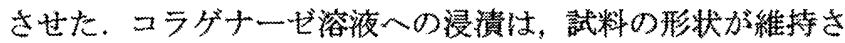

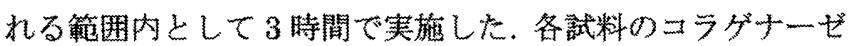

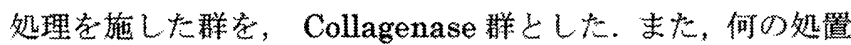

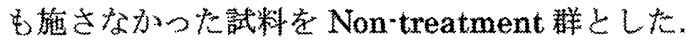

\section{2-3 䉼面積測定}

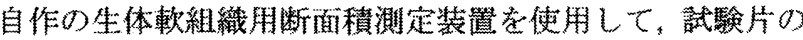

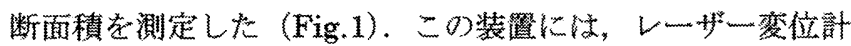

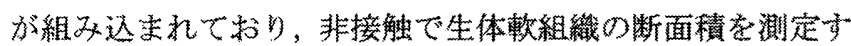

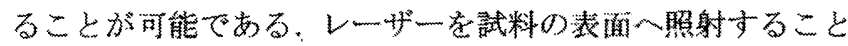

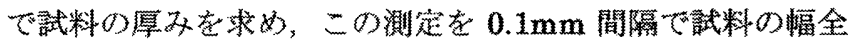

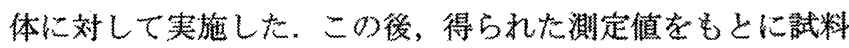

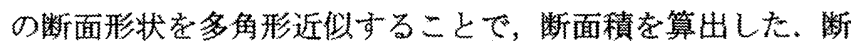

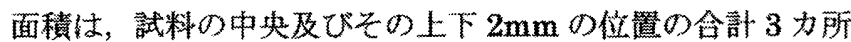
で測定し，それらの平妁值を試驗片の断面筫とした。

\section{$2-4$ 引聯試験}

ひず㹬測用のマーカーとして, 長軸方向に離れた 2 本の

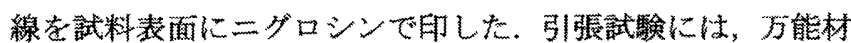
料䳝験機（EZ Test/CE，島津製作所）老使用した（Fig.2）。

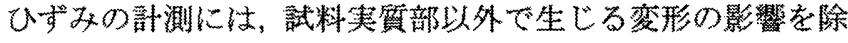

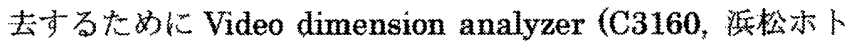

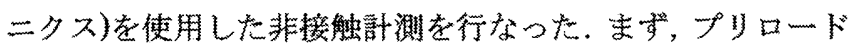

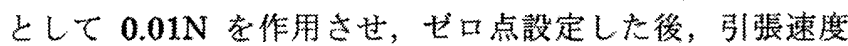

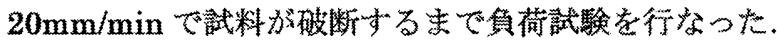

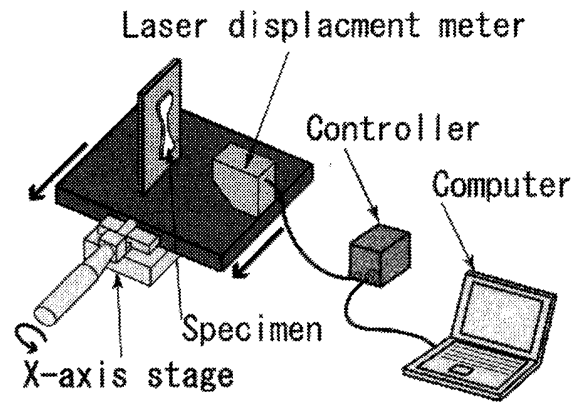

Fig.1 Apparatus for the measurement of cross-sectional area. 


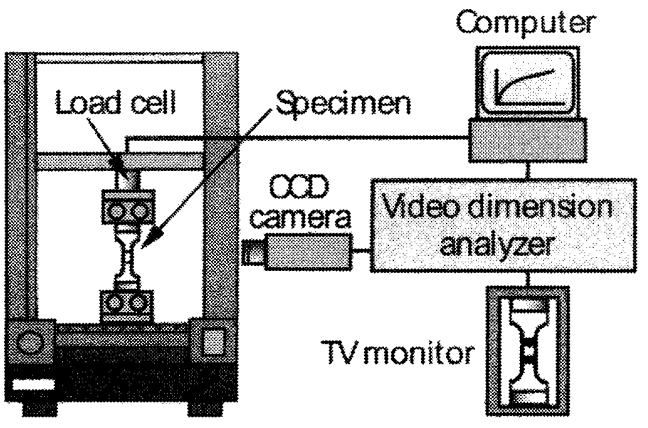

Fig.2 Schematic diagram of a tensile tester.

\section{3. 実験結果および考察}

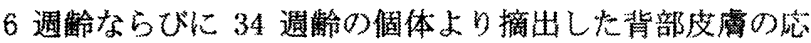

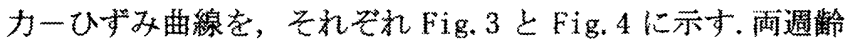

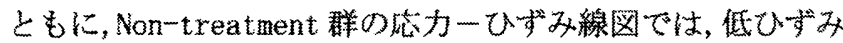

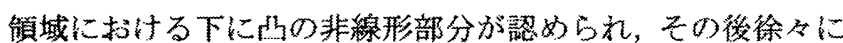

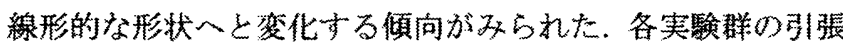

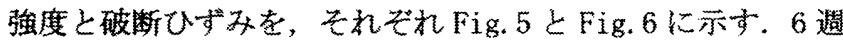

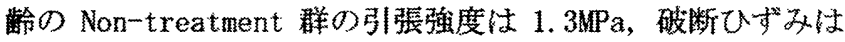
28.9\%で茄った。これに対して，34 邀龄の Non-treatment 群

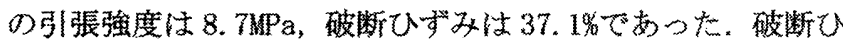

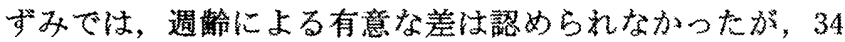
週龄の引張強度は，6週龄に比心゙て6.6倍となっでり，有

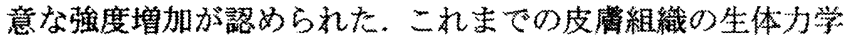

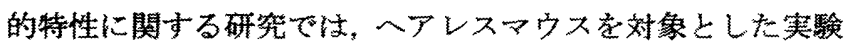
が行なるれている場合が汪とんどである [1]、今回䚵測した 成長期と成熟期の皮膚組織に関古る力学的特性仗，へアレス ラットを用いた波清科領域の研焭を推進していくたで必要 不可欠な基礎デー夕堂提供するもの上考えられる.

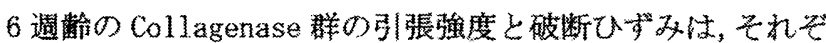
れ0.8MPa,19\%であった。これらの值は, Non-treatment 群の

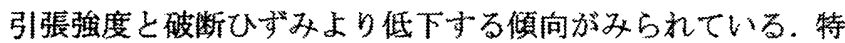
に引張強度の低下は著しく，Collagenase 群の値は Non-treatment 群の $58 \%$ であった。一方，34 週梌での Collagenase 群と Non-treatment 群の力学的特性の相違は 6

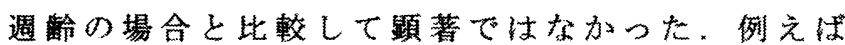
Collagenase 群の破断结力は Non-treatment 群の 80\%であっ

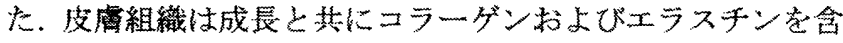

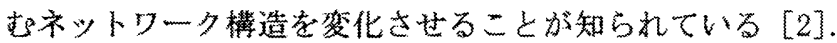
成長過程にあるコラーダン線維の配问や分者は，成熟した䋧

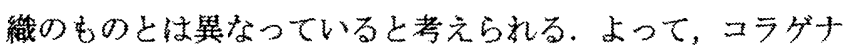

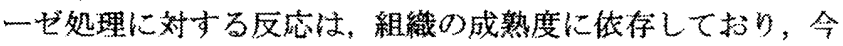
回の赛験結果のように末成熟組織ではコラダナーーー㐐理に よる強度低下が影著になるもの上推察される。

\section{参考文献}

[1]Matsumoto, T , et al., 2010, Skin Research and Technology, Vol, 16, pp. 179-189.

[2] Elizabeth, C., et al., 2011, Matuitas, Vol. 69, pp. 249-256.

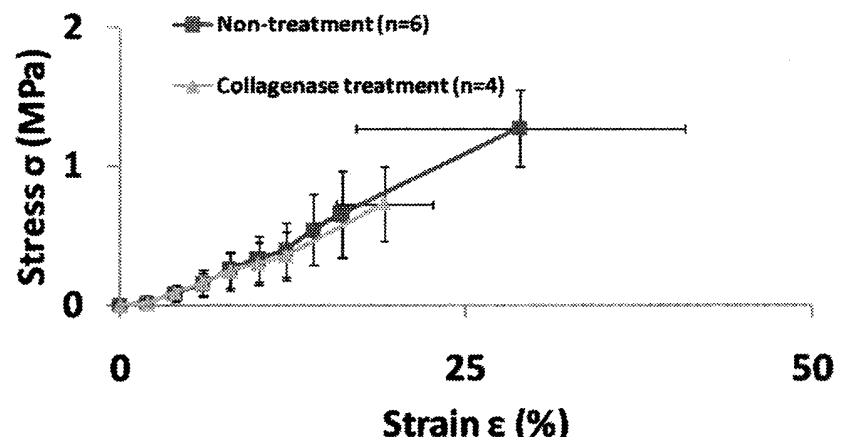

Fig. 3 Stress-strain relations ( 6 weeks)

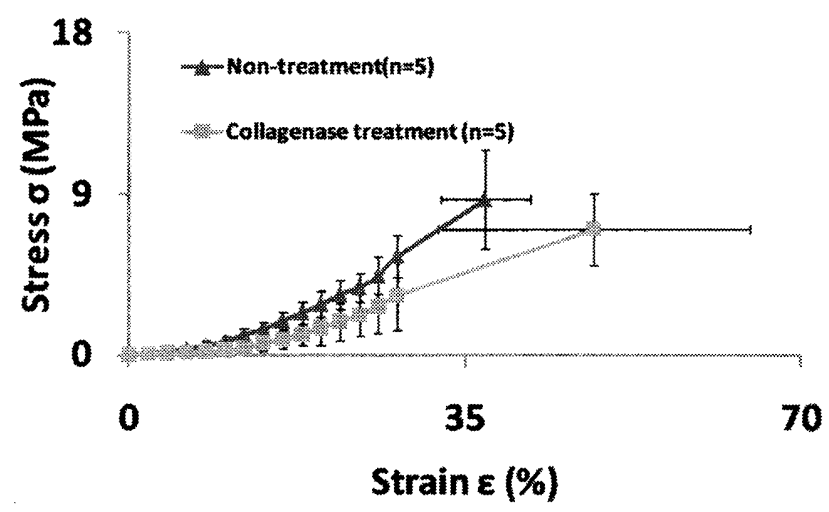

Fig. 4 Stress"strain relations ( 34 weeks)

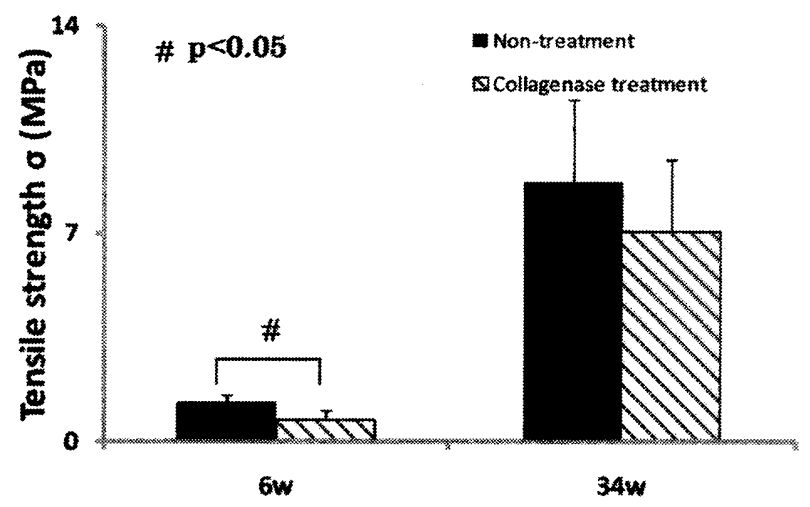

Fig.5 Tensile strength

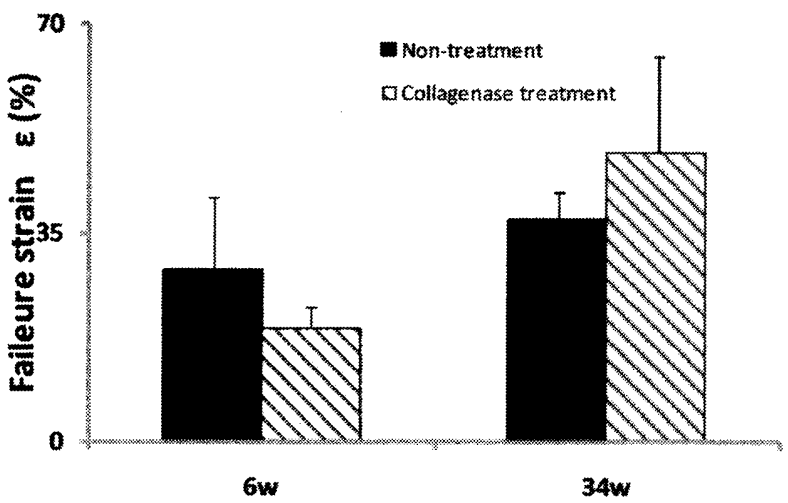

Fig.6 Failure strain 